\title{
The Effect Of Financial Ratio On Company Value With Inflation As A Moderation Variable
}

\author{
Herman Ruslim and Michael \\ Fakultas Ekonomi Universitas Tarumanagara \\ Lulusan Magister Akuntansi - Fakultas Ekonomi-Universitas Tarumanagara \\ Email: herman.ruslim@gmail.com,michael.lie159@gmail.com
}

\begin{abstract}
This study empirically examines the effect of capital structure, company growth, and profitability on firm value with inflation as a moderating variable in issuers in 2012-2015. The sample of this study was 245 issuers. The research method uses the Generalized Method of Moments (GMM) method. The result of this study is indicated that partially positive and significant effect on firm value (PBV) is the capital structure variable (DAR) and profitability (ROA), while company growth (growth) partially has a negative and no significant effect on firm value. Therefore, inflation moderates the effect of the relationship of profitability on firm value. The result of Simultaneous test showed that there is a significant effect of capital structure, company growth, profitability, and inflation simultaneously on firm value. This is indicated by the result of R-squared $19.3141 \%$ which indicated that variations in company value can be explained by variable capital structure, company growth, profitability and inflation of $19.3141 \%$ and the remaining $80.6859 \%$ explained by other factors.
\end{abstract}

Keywords: capital structure, company growth, profitability, inflation, firm value.

\section{INTRODUCTION}

Global economic conditions have experienced a slowdown lately causing prices of shares of public companies on the Indonesia Stock Exchange (IDX) to also decline. Stock prices as a representation of company value are determined by internal factors and external factors of the company. These factors are factors that are often used by investors in making decisions in the capital market. Besides fundamental factors, important factors that influence stock prices use technical factors.

Fundamental aspects are the basic basis of valuation, this is because the value of the company's shares is not only intrinsic value but also hopes for the company's ability to increase wealth in the future. Companies have various ways to increase company value; one of them is by evaluating variables that can affect company value.

Macroeconomic factors play a role in the analysis of capital markets, such as when inflation rises, usually accompanied by an increase in interest rates furthermore, it cannot be controlled, this factor is uncontrollable. Fundamental macro factors include factors: (1) Social, Culture (2) Economy, (3) Technology (4) Power and (5) competition (Yanuar, 2011). Nevertheless, this research is only limited to inflation as a macroeconomic fundamental factor, because economic factors are a factor that is often a concern of capital 
market agents. Inflation has a tendency to influence capital market players either directly or indirectly.

Micro factors as the company's fundamental factors in the analysis of the capital market and are controllable so that they can be controlled by the company. These factors can be grouped into funding policies and company performance factors (Ross and Waterfield, 2015). The funding policy is proxied by the structure of debt to assets (debt to asset ratio, DAR). While company performance factors can be reflected in the financial performance aspects that are proxied by company growth (growth) and the level of asset returns (return on assets, ROA).

Investment in stocks is categorized as a high-risk investment because it is very dependent on macroeconomic factors that can cause systemic risk, where systemic risk cannot be lost by diversification or often also referred to as market risk. If the macroeconomy is disrupted, the stock price has the potential to rise or fall as a whole. The relationship between the economy and the capital market is in the same direction. Historically, stock prices were very sensitive indicator indicators in the business cycle.

The first variable that can influence company value is the capital structure. According to (Brigham and Houston, 2011), the optimal capital structure in a company is a combination of debt and equity that maximizes the company's stock price. The capital structure showed that the alternatives used by companies to finance their capital (Saleem et al., 2013), (Pahuja and Sahi, 2012) stated that the optimal capital structure is balancing risk and profit so that there is a capital structure target in maximizing stock prices.

Several previous studies showed that the capital structure has a positive and significant influence on firm value. However (Chowdhury and Chowdhury, 2010), found that capital structure has a negative and significant influence on firm value. (Mule and Murkas, 2015), also found that capital structure has a negative and significant effect on firm value. However (Salim and Yadav, 2012), (Ramadan, 2015), (Fumani and Moghadam, 2015), (Asif and Aziz, 2016), found that the capital structure has a positive and significant effect on company value.

The second variable that can influence the value of a company is the growth of the company which is indicated by the growth of assets that can affect the value of the company. According to (Abdul, 2015) mentioned that asset growth as a change in assets per year. The growth of assets in a company is one form of investment activity carried out by the company.

Several previous studies conducted by Arfan and Rofizar, (2013), showed that the growth of the company had a positive and not significant effect on the value of the company. However (Rasyid, 2015) found that company growth has a negative and significant influence on firm value. And (Yuanita et al., 2016), also found that company growth had a negative and no significant effect on firm value. But, contrary to the research above, (Ardi et al., 2016) found that company growth has a negative and significant influence on firm value. However (Majid and Benazir, 2015) found that company growth has a positive and significant effect on firm value.

The third variable that can affect company value is profitability. The research from (Damodaran, 2012) mentioned that profitability is how much the company is able to generate profits from sales and investment companies. According to (Brigham and Houston, 2011) indicated that profitability is the end result of income hence generating 
positive operating cash flows can be used to finance investments and return on capital in the form of dividends and increase company liquidity.

Previous studies have shown better performance measurement, finding that ROA has a positive and significant influence on firm value. In contrary, (Chen and Chen, 2011), and (Kabajeh et al., 2012), found that ROA has a positive and significant effect on firm value. However (Placindo, 2012), (Moridipour and Farrahipour, 2013), found that ROA has a negative and significant influence on firm value. In accordance with the concept of signaling theory from (Suad and Enny, 2015), naturally, ROA can be a signal of information on the benefits that can be obtained in the future. Therefore, ROA has a positive and significant relationship with Company Value.

Furthermore, one of the economic crises as an external factor affecting stock prices or company value is inflation. Inflation is one of the macro variables that affect stock market prices in the capital market. The inflation rate indicates an investment risk that affects investor behavior in investment activities.

High inflation conditions can cause prices to rise in raw material production so that production prices increase and it ultimately causes the expected costs to increase and inflation which is caused by cost-push inflation. Inflation can also cause a decrease in demand which causes profitability to decline. Based on this explanation, the increase in inflation can reduce the level of profitability and market value of the company and vice versa if inflation tends to decline, causing the company's profitability tends to increase thus the changes in inflation affect the profitability of the company (Suad and Enny, 2015)

Previous research on the effect of inflation on company value according to (Mgammal, 2012) stated that inflation has a negative and significant effect on company value supported by (Kitati et al., 2015) found that inflation has a negative and no significant effect on firm value. While the result of the research conducted by (Ifeanyi and Chukwuma, 2016) indicated that the relationship between inflation and profitability had a non-significant negative effect on firm value. But according to (Al-Sharkas, 2016), and (Jubaedah et al., 2016), stated that inflation has a positive and significant effect on firm value.

\section{THEORETICAL REVIEW}

The value of the company. According to (Weston and Copeland, 2013) indicated that company value as investor perceptions of economic benefits from ownership of assets owned. Stock market value reflects the perceptions of the market players' perceptions of the company's value (Damodaran, 2012). The value of the company is determined by the company's cash flow generated by the company. Therefore Company Cash Flow is the sum of net income plus depreciation minus changes in working capital and capital expenditure. In other words, the value of the company will increase if the company's profitability also increases. High stock prices make the value of the company also high. The high corporate value will make market participants believe not only in current performance but also in the company's prospects. The main objective of the company is to maximize the value of the company because maximizing the value of the company also means maximizing the welfare of shareholders (Ross et al., 2015). In fact, the conflict that arises between the agent (company manager) and the Principal (company owner) has other possible goals contrary to the main purpose. Ideally, managers act best for the benefit of 
shareholders. This conflict is an agency problem (Damodaran, 2012). This agency problem arises between agents, principals, and shareholders. Not infrequently the actions of managers have a tendency to expand power by increasing the scale of the company by buying other companies (corporate actions).

Another researcher (Irham, 2014) stated that signaling theory is a company that gives market signals about market price fluctuations, for example, stock prices, bonds and so on by stock buybacks, stock split, bond buybacks, the stock reversed, thus giving an influence on investor decisions. Market players' responses to signals can be positive and negative, investors will react in response to these signals, such as buying shares or not reacting like "wait and see" or wait.

The main measure of prosperity, to shareholders (investors), is value. With the higher, the value of the company, the prosperity of the investor or the owner is increased. One indicator that can be found in the company is a public company is the market value of the company's shares. (Sri Hermuningsih, 2012), stated that fair market prices without coercion and pressure formed by buyers who are interested in buying and sellers who are interested in selling are called company market values because stock market prices reflect the company's prospects or ability to generate positive cash flows in the future. Investment opportunities provide a positive signal about the company's growth prospects, so they can increase the company's market value.

In Indonesian (Appraisal Standard SPI 330, 2018), there are 3 (three) assessment approaches, as follows:

1. Market Approach. The market approach compares comparable and similar companies by having looked at financial ratios in the same period recorded on the market for comparable and similar company shares and then comparing market price offers to comparable and similar companies.

2. Income Approach. The income approach can be used to estimate value by anticipating and quantifying the ability of Object Valuation to generate returns that will be received in the future.

3. Asset Approach. The asset approach is carried out by using the asset valuation results so as to obtain a fair market value for the tangible assets, and then adjusting the book value to the market value of tangible assets, the difference in book value and asset value is recorded in equity, after adjusting total assets minus total liabilities, resulting in market value stock.

Of the 3 (three) approaches, in this study, the author uses a market approach in conducting research on the value of the company. (Brigham and Houston, 2011) stated that there are various approaches to ratio analysis in market value valuation, consisting of the price-earnings ratio (PB), price to book value ratio (PBVR), market to book ratio (MBR), 10 yield ratio dividends, and dividends payout ratio (DPR). The company value in this study was measured by price to book value (PBV). What is meant by the ratio of stock prices to the book value of the company or PBV is the closing price of shares and the book value of companies in the non-financial industry on the Indonesia Stock Exchange in the period 2012-2015. The closing price and book value of these shares are taken directly from the Indonesia Stock Exchange website. Price to book value (PBV) showed a comparison of stock market prices that are capitalized with equity values recorded in the book to see the company's ability to generate market value for the company. A high PBV reflects a high share price compared to the value of a share (Husnan and Enny 2015). 
Capital Structure Theory. Tradeoff theory views companies as having optimal capital structure targets. The advantage of the tax return from debt usage compared to the expectations of bankruptcy costs due to the use of debt. Pecking Order Theory Companies prefer internal funding, if external funds are needed, the company will conduct debt financing, hybrid securities and finally with equity (Suad and Enny, 2015). If there are two companies that produce the same operating profit, but one uses a loan and pays interest while the other does not, then the company that pays interest will pay smaller taxes and the tax savings benefit the owner of the company. So the value of the company is a greater value that uses debt than companies that do not use debt.

Agency Theory. The researcher (Damodaran, 2012) stated that agency cost of outside equity: discussing conflicts between shareholders and managers. Agency Cost of Debt: Discusses conflicts between shareholders and creditors stating that between owners and management have different interests. This theory stated that the principal, such as the owner with an agent, the manager has a conflict in achieving the goal. Each party tries to increase profits for itself.

Signaling Theory. Expressing that the company provides a signal for every corporate action. According to (Brigham and Houston, 2011) a signal is an act of the company to give a sign or signal to investors about management looking at the prospects of the company. The signal is general information about what the management has done in realizing the principal's wishes.

The value of the company. The market value of a company's stock reflects an estimate of the amount of money that can be received or paid for the exchange of an asset or liability at the valuation date (SPI and KEPI, 2018). The main goal of the company according to the theory of the firm is to maximize the wealth or value of the company (Suad and Enny, 2015).

Capital Structure. (Damodaran, 2012) stated that capital structure is a mixture of longterm funding sources used by the company. Capital structure theory explains whether there is an effect of changes in capital structure on firm value if investment decisions and dividend policies are held constant. Another capital structure theory is the Puzzle Capital Structure Theory (Adnan Gharaibeh, 2014). This theory stated that the owner of the company chooses to buy his/her shares back when the stock price is undervalued, and issue new shares when the stock price is overvalued. Alternatively, the company will issue a debt when the company's share price is traded in an undervalued condition. This study concluded that the company will have stable leverage in only about 20 years. Most variations in capital structure are not time-invariant and most capital structure variations are not influenced by existing model specifications.

(Ela et al., 2016) mentioned that the theory of Trade-Off in this capital structure sees companies as having optimal capital structure targets. The advantage of tax returns from debt usage compared to the expectations of bankruptcy costs due to the use of debt. Pecking Order theory, companies prefer internal funding, if external funds are needed, the company will conduct debt funding, hybrid securities and finally with equity. 
Company Growth. Every company strives to achieve high growth every year because the growth of the company provides an overview of the company's development. Growth is how far the company places itself in the overall economic system or economic system for the same industry (Damodaran, 2012).

Profitability. (Ela et al., 2016) stated that profitability is a measure to assess a company's ability to make a profit. Profitability is used to measure the extent of the effectiveness of overall management in creating profits for the company. The company's ability to keep competing in competition with other companies requires companies to increase profitability. In this study, the profitability ratio used is the return on assets (ROA). The higher the ROA will be the greater the company's ability to generate profits. The high value of ROA indicated the ability of the company to generate profits for the owner of the company and provide a positive signal to generate profits so that stock prices tend to rise.

Macroeconomic Factors. (Yanuar, 2011) mentioned that an external condition that has an influence on company policy, company performance, and company value. Macroeconomic factors also influence investors in terms of investment, especially the variables of inflation, interest rates, and Gross Domestic Product (GDP). Indicators of bullish economic conditions are also reflected in inflation, low interest rates, and domestic gross products which tend to increase every year. Investors in investing also pay attention to overall macroeconomic conditions, when economic conditions are bad investors tend to hold or wait, but when economic conditions improve, investors will tend to invest such as controlled inflation, and lending rates and GDP increase sustainable.

This research included macroeconomic factors as the variables studied are inflation. The Inflation variable that was used in this research was that annual inflation was derived from Bank Indonesia inflation data, annual inflation was obtained by summing the monthly inflation average (12 months) moreover annual inflation can be known. The scale used in measuring inflation is the ratio scale. 


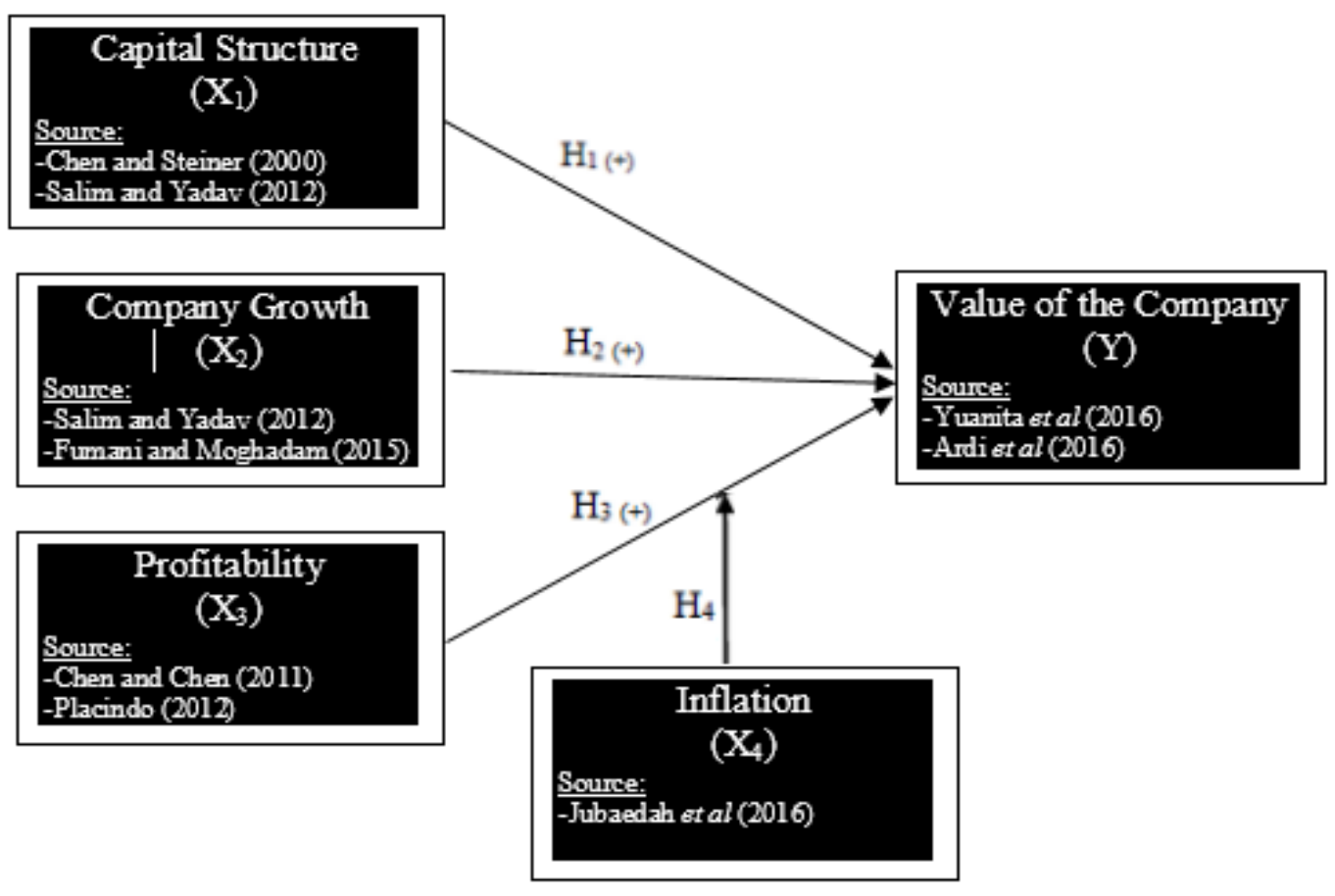

Figure 1. Framework Effect of Capital Structure, Corporate Growth, Profitability and Inflation on Company Values

Note:

$\mathrm{X} 1$ : Capital Structure

$\mathrm{X} 2$ : Company growth

X3: Profitability

X4: Inflation

Y: The value of the company

Sumber: source

The research design contains details of all procedures for obtaining and analyzing empirical data. The research uses quantitative data on non-financial companies listed on the Indonesia Stock Exchange from 2012 to 2015 to examine the effect of capital structure, company growth and profitability on company value with inflation as a moderating variable. In this study, the research population is a company engaged in all sectors of industry (agriculture; mining; basic industry and chemicals; miscellaneous industry; consumer good industry; property, real estate and building construction; infrastructure, utilities and transportation; trade, service and investment) except in the financial sector that are listed on the Indonesia Stock Exchange (go public) in 2012-2015, which amounted to 524 companies.

There are two sampling methods with probability and non-probability methods. In this study, the sampling method used is the sampling probability. Certain criteria used in the selection of samples are companies engaged in the non-financial sector that have been listed on the Indonesia Stock Exchange from 2012 to 2015 and have completed annual 
financial data from 2012 to 2015. Based on predetermined criteria, the number of companies used as samples is 245 companies.

The use of data analysis technique is using a general estimation method (generalization), known as the Generalized Method of Moment (GMM) regression method through the e-views 9-program (Sarwono, 2016). The data used is panel data, because it contains repeated time series observations $(\mathrm{T})$ for a large number $(\mathrm{N})$ of cross-sectional units (companies). Analysis of Descriptive Statistics: Normality Test, Classical Assumption Test, Hypothesis Test.

\section{RESULT AND DISCUSSION}

Normality test that is normally distributed which showed the significance value of the Jarque-Bera coefficient having a value smaller than 0.05 for the research variable. While the variable capital structure, company growth, profitability, inflation, and company firm value have a value greater than 2 . Both of these indicated that the data is not normally distributed. Classic assumption test is not needed because it is efficient by using the Generalized Method of Moment (GMM) regression. The result of the study is as follow:

\section{Table 1.}

Descriptive Statistics for the whole 2012 - 2015

\begin{tabular}{|l|c|c|c|c|c|c|}
\hline & PBV & DAR & GROWTH & ROA & INFLASI & $Z$ \\
\hline Mean & 1.687005 & 0.474563 & 0.153173 & 0.043945 & 0.060975 & 0.002755 \\
\hline Median & 1.117494 & 0.472609 & 0.113627 & 0.037584 & 0.063300 & 0.002139 \\
\hline Maximum & 9.128972 & 1.202499 & 2.125683 & 0.345252 & 0.083800 & 0.020078 \\
\hline Minimum & 0.049962 & 0.019471 & -0.719734 & -0.371663 & 0.033500 & -0.015180 \\
\hline Std. Dev. & 1.558867 & 0.196918 & 0.227091 & 0.069037 & 0.022984 & 0.004261 \\
\hline Skewness & 1.850244 & 0.107909 & 2.900478 & -0.146325 & -0.063415 & 0.500308 \\
\hline Kurtosis & 6.867019 & 2.577567 & 21.20915 & 6.949781 & 1.084176 & 5.128750 \\
\hline & 1169.771 & 9.188581 & 14913.32 & 640.5286 & 150.5308 & 225.9231 \\
\hline Jarque-Bera & 0.000000 & 0.010109 & 0.000000 & 0.000000 & 0.000000 & 0.000000 \\
\hline Probability & & & & & & \\
\hline Sum & 1653.265 & 465.0714 & 150.1094 & 43.06642 & 59.75550 & 2.700013 \\
\hline Sum Bq. Dev. & 2379.035 & 37.96240 & 50.48726 & 4.665959 & 0.517158 & 0.017775 \\
\hline Observations & 980 & 980 & 980 & 980 & 980 & 980 \\
\hline
\end{tabular}

Source: Processed Data

Table 1 is illustrated the characteristics of the variables studied. It is known that the number of samples is 980 samples, which is from 245 non-financial companies that have been listed on the Jakarta Stock Exchange since 2012 and the rest are still registered until the end of the 2015 observation period, have complete financial report data. The object of this research is the capital structure (debt to asset ratio, DAR), company growth, profitability (return on assets, ROA) and inflation. In this study, the use of variables is company value (price to book value, PBV) as the dependent variable and independent variables which include capital structure (debt to asset ratio, DAR), company growth, profitability (return on assets, ROA), and moderate variables, such as inflation. 
The description of the object of research can be seen in Descriptive Statistics which is processed using the program E-views 9. This analysis aimed to explain the average value (mean) and standard deviation of the comparison between the independent variables and moderate variables on the dependent variable.

Based on Table 1, it can be stated that the average value of the company (price to book value, PBV) of the sample studied is 1.687005 , while the median value of the company (price to book value, PBV) is 1,117494 . The maximum value of the company value (price to book value, $\mathrm{PBV}$ ) is 9,128972 which is the company's value to book value at PT Trada Maritime Tbk in 2013, while the minimum value of the company value (price to book value, PBV) is 0.049962 which is the price of book value owned by PT Indika Energy Tbk in 2015. The amount of standard deviation or deviation that occurs in the company value (price to book value, PBV) is 1.558867 . The mean value of the capital structure (debt to asset ratio, DAR) during the observation period is 0.474563 , while the median value of the capital structure (debt to asset ratio, DAR) is 0.472609 , where the value the maximum capital structure (debt to asset ratio, DAR) is 1.202499 which is the debt to asset ratio (DAR) of PT Indomobil Sukses International Tbk in 2014 and the minimum capital structure (debt to asset ratio, DAR) is in the amount of 0.019471 which is a debt to asset ratio (DAR) owned by PT Akbar Indo Makmur Stimec Tbk in 2013, with a level of deviation or standard deviation in the capital structure (debt to asset ratio, DAR) of 0.196918 .

The average value (means) of company growth (growth) of the sample under this study is equal to 0.153173 , while the median value of company growth is 0.113627 . The maximum value of company growth is 2.125683 which is the growth of the company belonging to PT Bhuawanatala Indah Permai Tbk in 2013, while the minimum value of company growth is equal to -0.719734 which is the company's growth PT Akbar Indo Makmur Stimec Tbk in 2012. The amount of standard deviation or deviation that occurs in the growth of the company is 0.227091 .

The average value (means) of profitability (return on assets, ROA) of the samples of this study is 0.043945 , while the median value of profitability (return on assets, ROA) is 0.037584 . The maximum value of profitability (return on assets, ROA) is 0.345252 which is the return on assets, ROA of PT Elang Mahkota Teknologi Tbk in 2012, while the minimum value of profitability (return on assets, ROA) is $-0,371663$ which is PT Trada Maritime Tbk's return on assets, ROA in 2015. The amount of standard deviation or deviation that occurs in profitability (return on assets, ROA) is 0.069037 .

The average value (means) of inflation from the sample under this study is 0.060975 , while the median value of inflation is 0.063300 . The maximum value of inflation is 0.083800 which is inflation in 2013 , while the minimum value of inflation is 0.033500 which is inflation in 2015 . The amount of standard deviation or deviation that occurs in inflation is 0.022984 . 
Table 2. The Result of Data Panel Regression Test with the GMM Method

\begin{tabular}{|c|c|c|c|c|}
\hline \multicolumn{5}{|c|}{$\begin{array}{l}\text { Dependent Variable: LOG_PBV } \\
\text { Method: Generalized Method of Moments } \\
\text { Date: } 12 / 1716 \text { Time: } 11: 56 \\
\text { Sample: } 1980 \\
\text { Included observations: } 980 \\
\text { Linear estimation with } 1 \text { weight update } \\
\text { Estimation weighting matrix: HAC (Bartlett kernel, Newey-west fixed } \\
\quad \text { bandwidth = } 7.0000 \text { ) } \\
\text { Standard errors \& cowariance computed using estimation weighting matrix } \\
\text { Instrument specification: DAR GROWTH ROA INFLASI Z2 } \\
\text { Constant added to instrument list }\end{array}$} \\
\hline Variable & Coefficient & Std. Error & t-Statistic & Prob. \\
\hline & & & & \\
\hline DAR & -0.242928 & & & \\
\hline GRONTH & -0.049962 & 0.065456 & -0.763294 & 0.4455 \\
\hline ROA. & 1.762978 & 0.507731 & 3.472268 & 0.0005 \\
\hline INFLASI & 0.377188 & 0.457771 & 0.823966 & 0.4102 \\
\hline$z$ & 16.77229 & 7.323768 & 2.290118 & 0.0222 \\
\hline R-squared & 0.193141 & Mom doman & ht var & 0.057765 \\
\hline Adjusted R-squared & 0.188999 & S.D. depend & t var & 0.399707 \\
\hline S.E. of regression & 0.359959 & Sum square & esid & 126.2014 \\
\hline Durbin-watson stat & 0.853006 & J-statistic & & 0.000000 \\
\hline Instrument rank & & & & \\
\hline
\end{tabular}

Source: Processed Data

From the result of the test above, the regression equation can be formulated as follows:

$$
\begin{gathered}
\text { Yit }=-0,242928+\text { 0,340656DARit }-0,049962 \text { GROWTHit }+ \text { 1,762978ROAit }+ \\
\text { 0,377188INFLASIit }+ \text { 16,77229Zit }+ \text { eit }
\end{gathered}
$$

From the result of this study, there are two non-significant variables, there are Growth and Inflation variables. As for the result of the study found growth does not have a positive and significant effect on firm value. This is due to investors overseeing industry prospects and company profits. This is supported by research conducted by (Wirawati, 2008), (Ali Kesuma, 2009), (Rosma Pakpahan, 2010), (Rasyid, 2015), (Yuanita et al., 2016), and (Ardi et al., 2016).

The inflation variable has no significant effect. This is due to the test samples used from the period 2012 to 2015 in stable economic conditions. Furthermore, the inflation variable is only used as moderation for profitability variables. The inflation moderation result on profitability found that this variable has a positive and significant effect on the company. While other variables that significantly influence company value are capital structure variables and profitability variables.

\section{CONCLUSION}

This research was conducted with the aim of analyzing and assessing the effect of capital structure, company growth and profitability on firm value with inflation as a moderating variable in non-financial companies listed on the Indonesia Stock Exchange in the period 2012 to 2015 . Based on the result of test and analysis were done by the author 
of 245 financial statements of the sample companies using the E-views 9 program, some conclusions can be drawn. Conclusions are taken based on the result of research both partially and simultaneously. The result of the study is indicated that:

1. The capital structure has a significant and positive effect on company value. The result obtained in this study is in line with the result of previous studies that showed the influence of capital structure on company value. The capital structure is closely related to the source of corporate funding. For each company, the decision in choosing funding sources is important because it will affect the company's financial structure, which will ultimately affect the value of the company.

2. The growth of the company does not have a significant positive effect on the value of the company. The result obtained in this study is not in line with the result of previous studies which showed the influence of company growth on firm value. This can happen because of inappropriate company policies towards growth within the company and also due to internal and external factors within the company.

3. Profitability has a significant and positive effect on company value. Large profitability showed that the company's performance is getting better because investors have an interest in paying attention and understanding the extent to which investments are made, able to provide a return on investment (return) as expected. Profitability produced by the company and high value will provide a good prospect for the company and furthermore, it can respond to investors to increase supply and demand for the number of shares. Increasing demand for shares will cause stock prices to increase and the value of the company will also increase.

4. Inflation moderates the effect of the relationship between profitability and company value. This is because inflation is very sensitive to affect profitability. The value of the company is not solely determined by the profit of the company, but there is an influence of macroeconomic indicators, one of which is inflation.

5. The capital structure, company growth, and inflation simultaneously have a significant effect on company value in non-financial companies listed on the Indonesia Stock Exchange in the period 2012-2015.

\section{REFERENCE}

Abdul Halim (2015). Menejemen Keuangan Bisnis, Konsep dan Aplikasinya, Edisi Asli, Penerbit Mitra Wacana Media.

Abdul Rasyid. (2015). "Effects of Ownership Structure, Capital Structure, Profitability and Company's Growth Towards Firm Value", International Journal of Business and Management Invention, ISSN: 2319 - 8028.

Adel, Al-Sharkas. (2016). "The Dynamic Relationship Between Macroeconomic Factors And The Jordanian Stock Market". International Journal of Applied Econometrics and Quantitative Studies, 1(1).

Anup, Chowdhury dan Suman Paul Chowdhury. (2010). Impact of Capital Structure on Firm's Value: Evidence from Bangladesh. BEH - Business and Economic Horizons, 3(3), 111-122.

Arthur J. Keown, David F. Scott, Jr., John D. Martin, J. William Petty (2010). Manajemen Keuangan: Prinsip dan Penerapan Jilid 1 (Edisi Kesepuluh). Jakarta: PT. Indeks. 
Asif, Ammara dan Aziz, Bilal. (2016). "Impact of Capital Structure on Firm Value Creation-Evidence from the Cement Sector of Pakistan". International Journal of Research in Finance and Marketing, Vol.6, ISSN 2231-5985.

Brigham, Fugune F dan Joel F. Houston. (2011). Fundamentals of Financial Management.

Chen, Carl R., and Thomas L. Steiner. (2000). "Tobins'Q, Managerial Ownership, and Analyst Coverage, A Nonlinear Simultaneous Equation Model". Journal of Economic and Business, 52, 365-385.

Chen, Li-Ju., and Chen, Shun-Yu. (2011). "The influence of profitability on firm value with the capital structure as the mediator and firm size and industry as moderators". Investment Management and Financial Innovations journal, 8 (3)

Damodaran, Aswath (2012). Investment Valuation, Tools and Techniques for Determining the Value of Any Asset, University Edition, John Willey.

David, Fred R. (2003). Strategic Management: Concepts and Cases. Ninth Edition. Prentice Hall. Upper Saddle River, New Jersey 07458.

Ela Mahdaleta, Iskandar Muda, Gusnardi Muhammad Nasir, (2016). Effects of Capital Structure and Profitability on Corporate Value with Company Size as the Moderating Variable of Manufacturing Companies Listed on Indonesia Stock Exchange. Academic Journal of Economic Studies.

Fumani, Maryam Alhani dan Moghdam, Abdolkarim. (2015). "The Effect of Capital Structure on Firm Value, The Rate of Return on Equity and Earnings Per Share of Listed Companies in Tehran Stock Exchange". Research Journal of Finance and Accounting, 6 (15).

Gharaibeh, Adnan (2014). "Capital Structure, Liquidity and Stock Returns". European Scientific Journal, 10 (25), ISSN:1857-7881

Husnan dan Enny (2015). Dasar-dasar Menejemen Keuangan. Yogyakarta: Unit Penerbit dan Percetakan UPP STIM YKPN.

Ifeanyi, Nando dan Chukwuma, Ugwu. (2016). "An Empirical Analysis of Inflationary Impacts on Profitability and Value of Selected Manufacturing Firms in Nigeria". Research Journal of Finance and Accounting, 7 (12).

Jensen, M., and W.H. Meckling. (1976). "The Theory of the Firm: Managerial Behavior, Agency Cost, and Ownership Structure". Journal of financial Economic, 3 (4), 305360.

Jubaedah, Yulivan, Ivan., Hadi, Abdul Razak. (2016). "The Influence of Financial Performance, Capital Structure and Macroeconomic Factors on Firm's Value Evidence from Textile Companies at Indonesia Stock Exchange". Applied Finance and Accounting, 2 (2).

Kabajeh.M.A.M, Nu'aimat S.M.A, Dahmash.F.A. (2012). "The Relationship between the ROA, ROE, and ROI Ratios with Jordanian Insurance Public Companies Market Share Prices". International Journal of Humanities and Social Science, 2 (11), June.

KEPI dan SPI, Kode Etik Penilai Indonesia dan Standar Penilaian Indonesia (2018), Edisi VII, penerbit MAPPI dan KPSPI.

Kitati, Edward., Zablon, Evusa., Maithya, Henry. (2015). "Effect of Macroeconomic Variables on Stock Market Prices for the Companies Quoted on the Nairobi Securities Exchange in Kenya". International Journal of Sciences: Basic and Applied Research, 21 (2), 235-263. 
Mahfuzah, Salim dan Dr. Raj, Yadav. (2012). Capital structure and Firm Performance: Evidence from Malaysian Listed Companies. Procedia Social and Behavioral Science, Issue 65, 156- 166.

Manaje Jr, Placido M. (2012). "Impact of Selected Financial Variables on Share Price of Publicly Listed Firms in the Philipines". American International Journal of Contemporary Research, 2 (9).

Mgammal, Mahfoudh Hussein Hussein. (2012). "The Effect of Inflation, Interest Rates And Exchange Rates on Stock Prices Comparative Study Among two GCC Countries". International Journal Of Finance And Accounting, 1 (6), 179-189.

Moridipour, Hamid and Farrahipour, Zahra. (2013). "The Evaluation Of The Relationship Between Price-To-Book Ratio And Accounting Variables”. International Research Journal of Applied and Basic Sciences. ISSN 2251-838X.

Muhammad Arfan dan Heny Rofizar. (2013). "Nilai Perusahaan dalam Kaitannya dengan Arus Kas Bebas dan Pertumbuhan Perusahaan”. Jurnal Telaah dan Riset Akuntansi, $6(1), 14-30$.

Mule, Robert Kisavi., and Mukras, Mohamed Suleiman. (2015). "Financial Leverage and Performance of Listed Firm in a Frontier Market: Panel Evidence from Kenya". European Scientific Journal, 11 (7).

Pahuja, Anurag., and Anus Sahi. (2012). "Factors Affecting Capital Structure Decision: Empirical Evidence From Selected Indian Firms". International Journal of Marketing, Financial Service \& Management Research. 1 (3). ISSN 2277-3622.

Pakpahan, Rosma. (2010). Pengaruh Faktor-Faktor Fundamental Perusahaan dan kebijakan Dividen Terhadap Nilai Perusahaan. Jurnal Ekonomi Keuangan, 2 (2).

Paminto, Ardi., Setyadi, Djoko., Sinaga, Jhony. (2016). “The Effect of Capital Structure, Firm Growth and Dividend Policy on Profitability and Firm Value of the Oil Palm Plantation Companies in Indonesia". European Journal of Business and Management, 8 (33).

Ramadan Imad Zeyad. (2015). “An Empirical Investigation Of the Trade-Off Theory: Evidence from Jordan". International Bussiness Research, 8 (4).

Ross, Waterfield, (2015). Essentials of Corporate Finance, John Willey.

Saleen, Sidra Tariq, and Ghazala Akram. (2013). "The Determinants of Capital Structure of Oil and Gas Firms Listed on Karachi Stock Exchange In Pakistan". Interdisciplinary Journal of Contemporary Research In Business, 4 (9).

Shabri Abd, Majid dan Benazir. (2015). “An Indirect Impact of the Price to Book Value to the Stock Returns An Empirical Evidence from the Property Companies in Indonesia”. Jurnal Akuntansi dan Keuangan, 17 (2), November, 91-96.

Sukirno, Sadono (2015). Makroekonomi - Teori Pengantar, Edisi Ketiga, Jakarta: Penerbit: PT Raja Grafindo Persada. 4 \& 397.

Thirteen Edition. New York: Thomson South-Western Mc Graw Hill.

Yanuar, (2011). Ekonomi Makro: Suatu Analisis Untuk Konteks Indonesia.

Yuanita, Missy, Budiyanto, dan Slamet Riyadi. (2016). "Influence of capital structure, size and growth on profitability and corporate value". International Journal of Business and Finance Management Research, ISSN 2053-1842. 